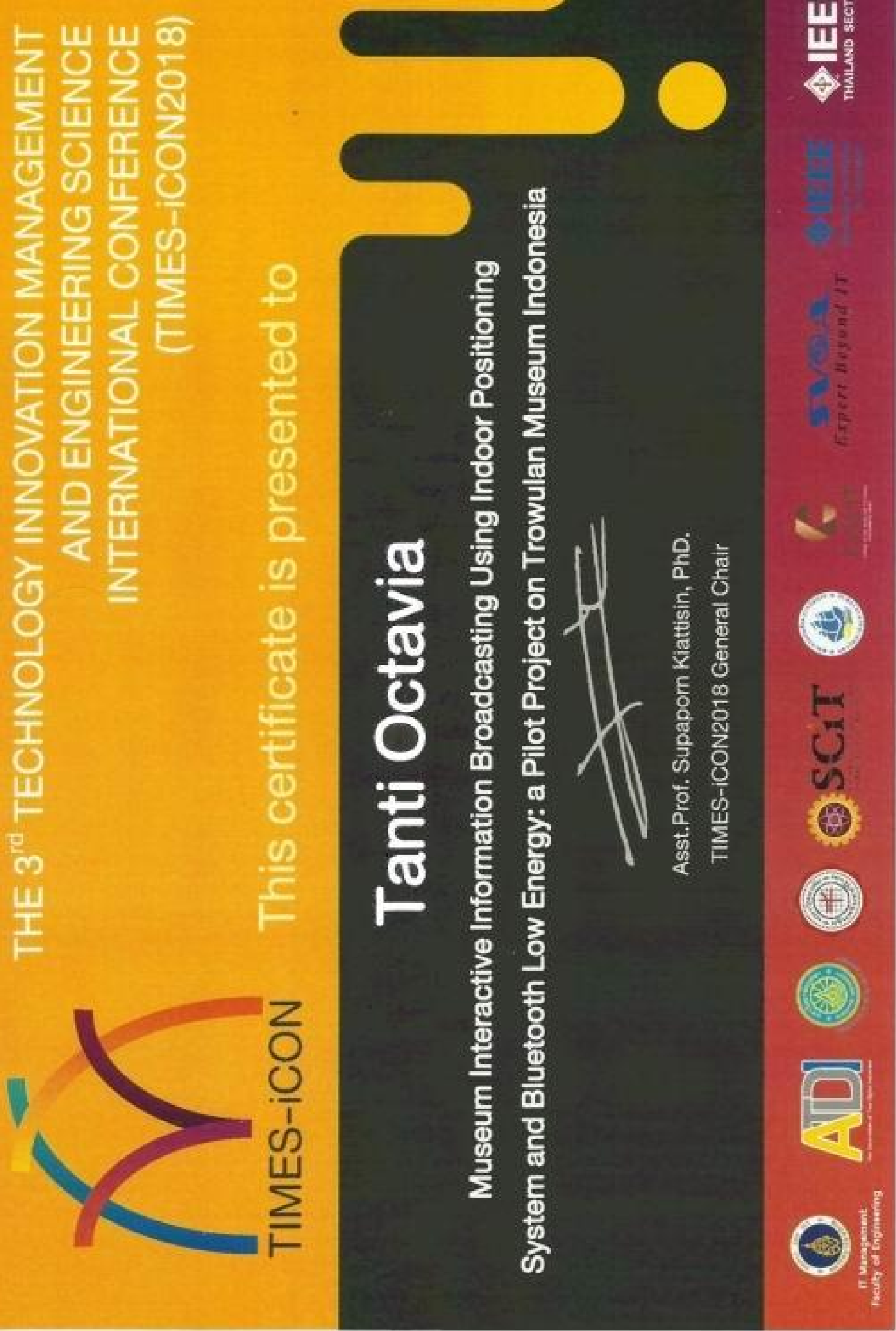




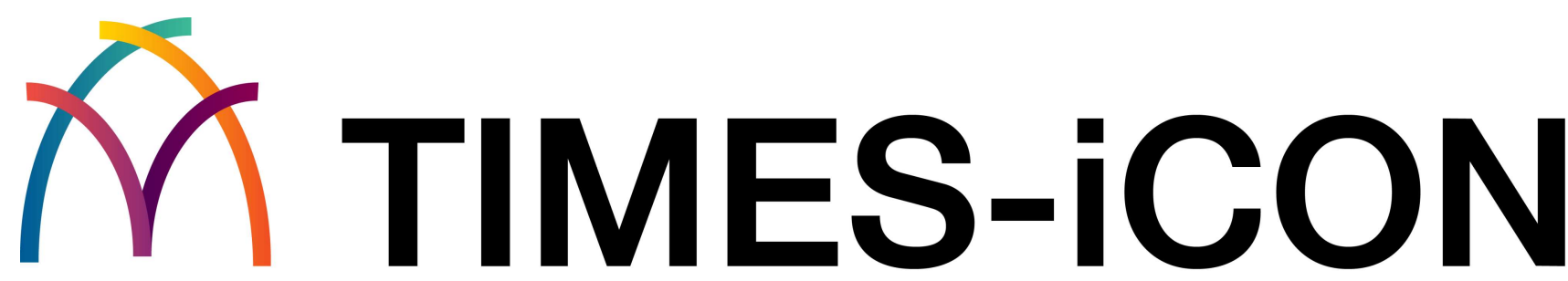

(http://times-icon.org/2018/)

Home

(http://times-icon.org/2018/)

Call for Papers

(CFP-TIMES-iCON2018.pdf)

Organizing Committee

(committee.html)

International Steering Committee

(International_Committee.html)

Important Dates

(important_date.html)

Conference Program new

(conf_program.html)

Keynote Speakers new

(keynote_speaker.html)

CameraReady

(cameraready.html)

Paper Submission

(PaperSubmission.html)

Registration

(registration.html)

Venue

(venue.html)

Past Conference (TIMES-iCON2017)

(http://times-icon.org/2017)

Past Conference (TIMES-iCON2016)

(http://times-icon.org/2016)

About us \& Contact us 


\section{TIMES-iCON2018}

December 12-14, 2018 Bangkok, Thailand

\section{Organizing Committee}

\section{Honorary Chair}

- Jackrit Suthakorn, Mahidol University

\section{General Chair}

- Supaporn Kiattisin, Mahidol University

\section{Technical Program Chair}

- Sotarat Thammaboosadee, Mahidol University

- Smitti Darakorn na Ayutthaya, Mahidol University

- Bunlur Emaruchi, Mahidol University

- Manutsiri Chansutthirangkool, Mahidol University

\section{Publicity Chair}

- Prush Sa-nga-ngam, Mahidol University

- Wasin Srisawas, Mahidol University

\section{Publication Chair}

- Adisorn Leelasantitham, Mahidol University

- Yutthapong Aunhataweesup, Mahidol University

- Jarurote Tippayachai, Mahidol University

\section{Local Arrangement Chair}

- Taweesak Samanchuen, Mahidol University

- Theera Piroonratana, Mahidol University

\section{Finance Chair}

- Chanattha Chansutthirangkool, Mahidol University

- Luksamee Chujai, Mahidol University

- Suchanya Ratsadonniyom, Mahidol University 
Steering Committee

- Adisorn Leelasantitham, Mahidol University

- Apichat Terapasirdsin, Rajamangala University of Technology Isan

- Apinan Aurasopon, Mahasarakham University

- Atichart Harncharnchai, Chiang Mai University

- Itthiphol Eampoonga, Mahasarakham University

- Kairoek Choeychuen, Rajamangala University Of Technology Rattanakosin

- Laor Boongasame, Bangkok University

- Manirath Wongsim, Mahasarakham University

- Nanti Suthikarnnarunai, University of the Thai Chamber of Commerce

- Nattasit Gerdsri, Mahidol University

- Orapadee Joochim, King Mongkut's University of Technology Thonburi

- Ornnapa Tasnaina, Kasetsart University

- Prasong Praneetpolgrang, Sripatum University

- Punnarumol Temdee, Mae Fah Luang University

- Ratchada Kongkajan, Thammasat University

- Roungsan Chaisricharoen, Mae Fah Luang University

- Sarunya Lertputtarak, Burapha University

- Somkeit Noamna, Chiang Mai University

- Sotarat Thammaboosadee, Mahidol University

- Supasit Lertbuasin, Burapha University

- Suphakant Phimoltares, Chulalongkorn University

- Taweesak Samanchuen, Mahidol University

- Thanatchaphan Petcharat, Prince of Songkla University

- Thanwadee Chinda, Thammasat University

- Thawatchai Suwanapong, Prince of Songkla University

- Watcharachai Wiriyasuttiwong, Srinakharinwirot University

- Waranyu Wongseree, King Mongkut's University of Technology North Bangkok

- Werapon Chirachalit, King Mongkut's University of Technology Thonburi

- Wimol San-umm, Thai-Nichi Institute of Technology

- Yodying Thanatawee, Burapha University

\section{General Secretaries}

- Adisorn Leelasantitham, Mahidol University

- Rojjalak Chuckpaiwong, Mahidol University 


\section{Document details - Museum Interactive Information Broadcasting Using Indoor Positioning System and Bluetooth Low Energy: A Pilot Project on Trowulan Museum Indonesia}

\author{
1 of 1 \\ $\rightarrow$ Export $\Perp$ Download More...>
}

TIMES-iCON 2018 - 3rd Technology Innovation Management and Engineering Science International Conference

22 January 2019, Article number 8621815

3rd Technology Innovation Management and Engineering Science International Conference, TIMES-iCON 2018; Bangkok; Thailand; 12 December 2018 through 14 December 2018; Category numberCFP18R77-ART; Code 144577

Museum Interactive Information Broadcasting Using Indoor Positioning System and Bluetooth Low Energy: A Pilot Project on Trowulan Museum Indonesia(Conference Paper)(Open Access)

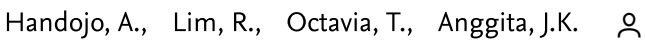

aInformatics Engineering Department, Petra Christian University, Surabaya, Indonesia

bElectrical Engineering Department, Petra Christian University, Surabaya, Indonesia

${ }^{c}$ Industrial Engineering Department, Petra Christian University, Surabaya, Indonesia

Abstract

The tourism sector become a promising country income. This is because its nature which is not easily run out if managed properly. This sector can be a great support especially for developing countries such as Indonesia, because usually developing countries income only rely on natural and human resources income. Museums are one of the tourism sectors that have not been explored properly. Museums in Indonesia are still few that using the latest technology such as smartphone application, wifi, bluetooth, RFID. So, that it makes the museum a less attractive place to visit, especially for young generation. This research tries to create an interactive broadcasting museum information by utilizing applications on smartphones, indoor positioning systems, and bluetooth low energy beacons to provide information to museum visitors about artifacts around museum visitor location. As a pilot project a testing was conducted at the Trowulan Museum, Mojokerto, East Java, Indonesia, which is a museum that exhibits the relics of the Majapahit kingdom. The application has been able to provide interactive information about artifacts around the visitor's location so as to create an interesting museum to visit. (C) 2018 IEEE.

SciVal Topic Prominence (i)

Topic: Near Field Communication | Mobile Payment | Ticket

Prominence percentile: $\quad 87.210$

(i)

Author keywords

Bluetooth Low Energy Indoor Positioning System Information Broadcasting Museum Smartphone

Indexed keywords

Engineering controlled terms:

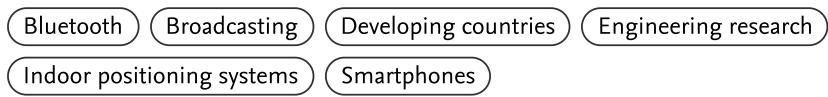

Engineering uncontrolled terms

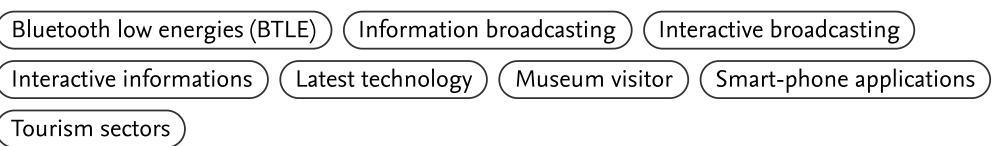

Cited by 2 documents

Handojo, A. , Octavia, T. , Lim, R.

Indoor positioning system using BLE beacon to improve knowledge about museum visitors

(2020) Telkomnika

(Telecommunication

Computing Electronics and Control)

Octavia, T. , Handojo, A. , Kusuma, W.T.

Museum interactive edutainment using mobile phone and QR code

(2020) Proceedings of 2019 the 9th International Workshop on Computer Science and Engineering, WCSE 2019

View details of all 2 citations

Inform me when this document is cited in Scopus:

$\begin{array}{ll}\text { Set citation } & \text { Set citation } \\ \text { alert }> & \text { feed }>\end{array}$

Related documents

Find more related documents in Scopus based on:

Authors > Keywords > 
$002 / S P 2 H / P / K 7 / K M / 2018$

\section{Funding text}

This research was supported by Indonesia Directorate Research and Technology of Higher Education under grant $002 / \mathrm{SP} 2 \mathrm{H} / \mathrm{P} / \mathrm{K} 7 / \mathrm{KM} / 2018$. We would also like to show our gratitude to the Mobile Computing Research Study Group for assistance to improve this research.

ISBN: 978-153867573-1

Source Type: Conference Proceeding Original language: English
DOI: 10.1109/TIMES-iCON.2018.8621815

Document Type: Conference Paper

Sponsors: The Association of Thai Digital Industries (ATDI)

Publisher: Institute of Electrical and Electronics Engineers Inc.

Handojo, A.; Informatics Engineering Department, Petra Christian University, Surabaya, Indonesia;

(C) Copyright 2019 Elsevier B.V., All rights reserved.

\section{About Scopus}

What is Scopus

Content coverage

Scopus blog

Scopus API

Privacy matters

\section{Language}

日本語に切り替える

切换到简体中文

切換到繁體中文

Русский язык

\section{Customer Service}

Help

Contact us

\section{ELSEVIER}

Terms and conditions $\pi \quad$ Privacy policy $\pi$

Copyright $\left(\right.$ Elsevier B.V $\boldsymbol{\pi}_{\text {. All rights reserved. Scopus }}{ }^{\circledR}$ is a registered trademark of Elsevier B.V.

We use cookies to help provide and enhance our service and tailor content. By continuing, you agree to the use of cookies. 


\title{
Museum Interactive Information Broadcasting Using Indoor Positioning System and Bluetooth Low Energy: a Pilot Project on Trowulan Museum Indonesia
}

\author{
Andreas Handojo ${ }^{1}$, Resmana Lim $^{2}$, Tanti Octavia ${ }^{3}$, Jonathan Kurnia Anggita ${ }^{1}$ \\ ${ }^{1}$ Informatics Engineering Department \\ ${ }^{2}$ Electrical Engineering Department \\ ${ }^{3}$ Industrial Engineering Department \\ Petra Christian University \\ Surabaya, Indonesia \\ handojo@petra.ac.id
}

\begin{abstract}
The tourism sector become a promising country income. This is because its nature which is not easily run out if managed properly. This sector can be a great support especially for developing countries such as Indonesia, because usually developing countries income only rely on natural and human resources income. Museums are one of the tourism sectors that have not been explored properly. Museums in Indonesia are still few that using the latest technology such as smartphone application, wifi, bluetooth, RFID. So, that it makes the museum a less attractive place to visit, especially for young generation. This research tries to create an interactive broadcasting museum information by utilizing applications on smartphones, indoor positioning systems, and bluetooth low energy beacons to provide information to museum visitors about artifacts around museum visitor location. As a pilot project a testing was conducted at the Trowulan Museum, Mojokerto, East Java, Indonesia, which is a museum that exhibits the relics of the Majapahit kingdom. The application has been able to provide interactive information about artifacts around the visitor's location so as to create an interesting museum to visit
\end{abstract}

Index Terms-Museum, Indoor Positioning System, Bluetooth Low Energy, Smartphone, Information Broadcasting

\section{INTRODUCTION}

Tourism industry has a big potential as a contributor to Indonesian revenue. This is very important especially for developing countries which generally cannot rely on country revenue from technological or industrial capabilities. Developing countries generally get their revenue from natural resources and human resources which are relatively cheaper than developed countries. The problem is this exploration of natural resources is limited and can be run out. This is different compared to the tourism. Tourism is one thing that cannot be exhausted as long as it is managed properly.

Indonesia as a developing country also has a similar problem. The largest country revenues from oil and gas, coal, and coal and palm oil (CPO). Therefore, the Indonesian government tries to develop the tourism sector as one of the alternative country revenue. In Indonesia, the tourism sector is the fourth largest country revenue contributor (9\%) [1]. Moreover tourism sector is also able to absorb 10 million workers. The government is targeting a significant increasing number of foreign tourists from 9 million (2014) to 20 million (2019) that will create 260 trillion rupiah (IDR) revenue [2].

According to Indonesia Minister of Tourism Arief Yahya, revenue from Indonesia's tourism sector continues to increase. Indonesia's tourism revenue in 2015 obtain US\$ 12,225 billion in the fourth position under CPO (US\$ 16,427 billion) and coal (US\$ 14,717 billion). The last acquisition of the tourism sector in 2017 was US\$ 16.8 billion (Detik.com, 2018). Until August 2017 foreign tourist arrivals increased by 25.68 percent [3]. It is expected that by the end of 2017 tourism sector foreign exchange earnings can reach US\$ 17.05 billion. Foreign tourist arrivals from January to August 2017 experienced the highest growth in Southeast Asia at $25.68 \%$. This figure is recorded higher than Singapore (3.83\%) and Thailand (5.05\%) [3]. Tourism minister report that in 2017 foreign tourist is increase rapidly (Fig.1) compare to 2016 data [4].

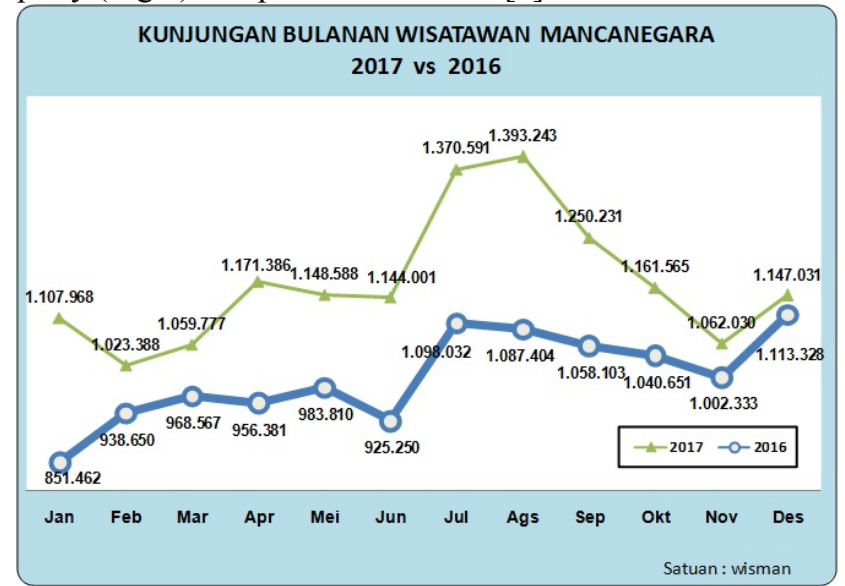

Fig. 1. Monthly Foreigner Tourist Data 2017 vs. 2016 [4] 
Indonesia has a huge potential in tourism sector considering that Indonesia is a country that has natural beauty, various ethnic groups, various cultures, and many historical relics such as temples that are scattered in various locations in Indonesia. Indonesia itself currently has 8 World Heritage Site locations from UNESCO. One potential tourism in Indonesia is a legacy of the past such as artifacts, ceramics, canons, weapons, sculpture, etc. This relics usually store on museums. Indonesia has around 400 museums scattered in various places in Indonesia [5]. Unfortunately the management of museums in Indonesia is still not optimal. Museum management in Indonesia still uses old mechanisms (such as pamphlets, signage, and website) without involving the latest technological advancements (such as smartphones, wifi, bluetooth, NFC). This, being one of the factors causing the museum to be a less attractive place to visit.

Another problem is the large amount of artifact information in the museum, in terms of the number of artifacts and the amount of information held by each artifact. Usually, for artifact information, museums in Indonesia still use text display which is very limited space of information that could be display. This is further worse by the inability to publish the information in non-written forms such as audio and video. So visitors do not get enough information about the artifacts they want to know. Another problem is the large number and types of artifacts that hold in a museum. Because usually the museum does not provide complete information about artifacts that store in the museum and its location. So, museum visitors must see one by one the existing artifacts without being able to directly go to the location of the artifact that they want to see and can spend more time in that location.

Based on the above problems, this study tries to build a museum visitor location detection application (Indoor Positioning System / IPS) using a Bluetooth low energy (BLE) beacon. Visitors can find out their current position on the museum map by using the application on the smartphone. From the information on the location of the visitor, visitors will receive a broadcast of information about the artifacts that are nearby. This information will be sent via the smartphone application. The application can also provide information about artifacts in other rooms. So, museum visitors can take advantage of this information to get to the artifacts that interest them. The application also comes with an interactive map of the museum along with artifacts in the museum. Visitors can find out more about the artifacts on the museum map by clicking on the artifact icon on the map. With this application, visitors are expected to get information about the location of artifacts in the museum interactively.

\section{LITERATURE REVIEW}

Several research efforts have been carried out in order to provide facilities for tourists by using information technology. Such as intelligent recommendations for tourist [6], NFC for tourism activities [7, 8], Location Based Services for tourists [9, 10], Surabaya battle tour using android applications and Google map API [11], tourism information application in
Ciamis district based on mobile phone [12], Solo information system application on mobile devices [13], and also using games and multimedia applications to build an interactive city tour [14].

Meanwhile, the use of information technology in providing facilities for museum visitors has also been carried out by several researchers such as games about museum via SMS on mobile device [15], audio information from as a mobile museum audio guide [16], a portal website to display additional information on museums [23], Ranggawarsita information system museum using mobile phone [18], and Perjuangan Indonesia Museum Information Application [19]. There is still a few research that explores delivering broadcast information to museum visitors based on the location of the visitor (indoor positioning system) in the museum using Bluetooth Low Energy (BLE).

On the other hand, research on indoor positioning system to find out the location of the user has been done. The equipment that is usually used for such purposes such as RFID, wifi, bluetooth, ultrasonic, and infrared signal. The IPS research purposes are quite various such as Manzano et al. [20] researched the indoor location finder for children using Bluetooth. Meliones et al. [21] creating an indoor blind navigator application as a tool to help blind people to be able to explore in a museum. Yucel et al. [22] develop indoor positioning system using ultrasonic and infrared signals. While Huang et al. [23] uses RFID and Kalman Filter to detect the location of goods.

Based on the research that has been done, there is still a few research that develops IPS to provide additional information about artifacts for museum visitors. Research also usually only reads user locations without broadcasting information to users. Therefore, in addition to detecting the location of the user, this research will also inform the user where the current user's position and artifacts are around the user. The location detection of the user will use a bluetooth connection on the smartphone that will detect the Bluetooth low energy (BLE) position of the beacon that has been placed in the museum rooms.

\section{IMPLEMENTATION}

This research use of BLE beacons as a tool for IPS detection with several considerations such as BLE Beacon requires a fairly low energy so the maintenance for batteries can be carried out about once a year. BLE beacons are small in size (Fig. 2), around $10 \mathrm{~cm} \times 2 \mathrm{~cm} \mathrm{x} 1 \mathrm{~cm}$, so that they can be easily placed in hidden places without disturbing the convenience of museum artifact displays. Because the small shape of the BLE beacon is also easily moved. In addition, BLE beacons also have easy setting so that they can be operated without special expertise. Especially BLE beacons have very cheap prices (around \$5) making them suitable for use in Indonesian museums. 


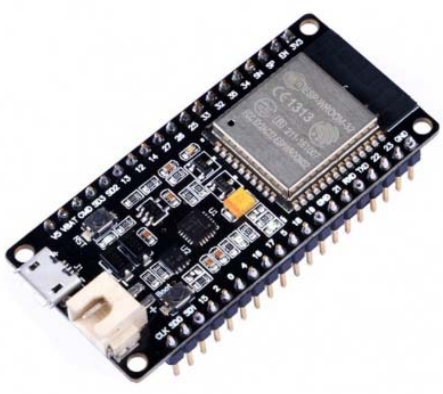

Fig. 2. Bluetooth Low Energy Beacon

The mechanisms of the interactive information broadcasting museum can be explained as follows (Fig. 3). The smartphone from the user captures a signal from the BLE Beacon. The smartphone automatically captures UUID from BLE devices and sends the UUID to the server via the internet. The server sends the information along with the coordinates of the BLE beacon on museum map. The application on the smartphone calculates the location based on BLE beacons signal strength (RSSI) that receive by the smartphone and the location of the BLE beacon coordinates. The user's location then mapped on the museum map that's available on the smartphone application. Based on that location, the server provides artifact information nearby to the user. Users can view detailed information on the smartphone application and also can go to the location of the artifact. With this information, museum visitors expected to get information on artifacts in the museum interactively.

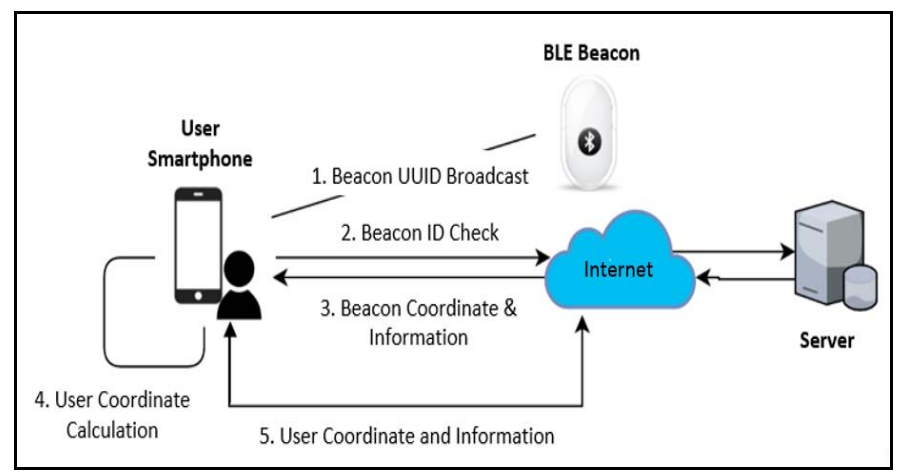

Fig. 3. Broadcast System Design

To make it easier for the museum administrator to arrange information and the location of the BLE beacons on the museum map. The research also provides a website-based facility for museum administrators to input museum maps and BLE beacon locations along with the radius of each beacon (Fig. 4). With this application, the museum administrator will easily adjust the location of the BLE beacons.

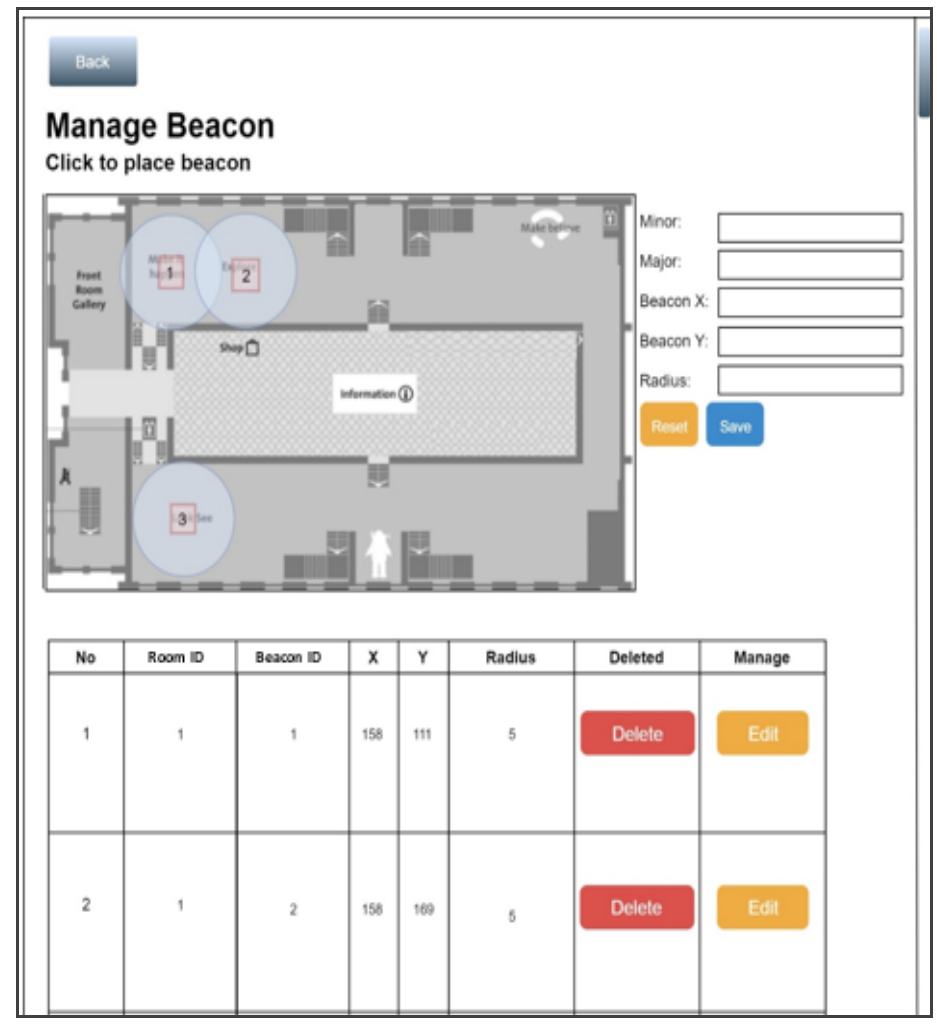

Fig. 4. Manage BLE Beacon Location

The museum administrator can also arrange information on the room inside the museum (Fig. 5). This information is useful for visitors to find out the location information of the room in the museum. 


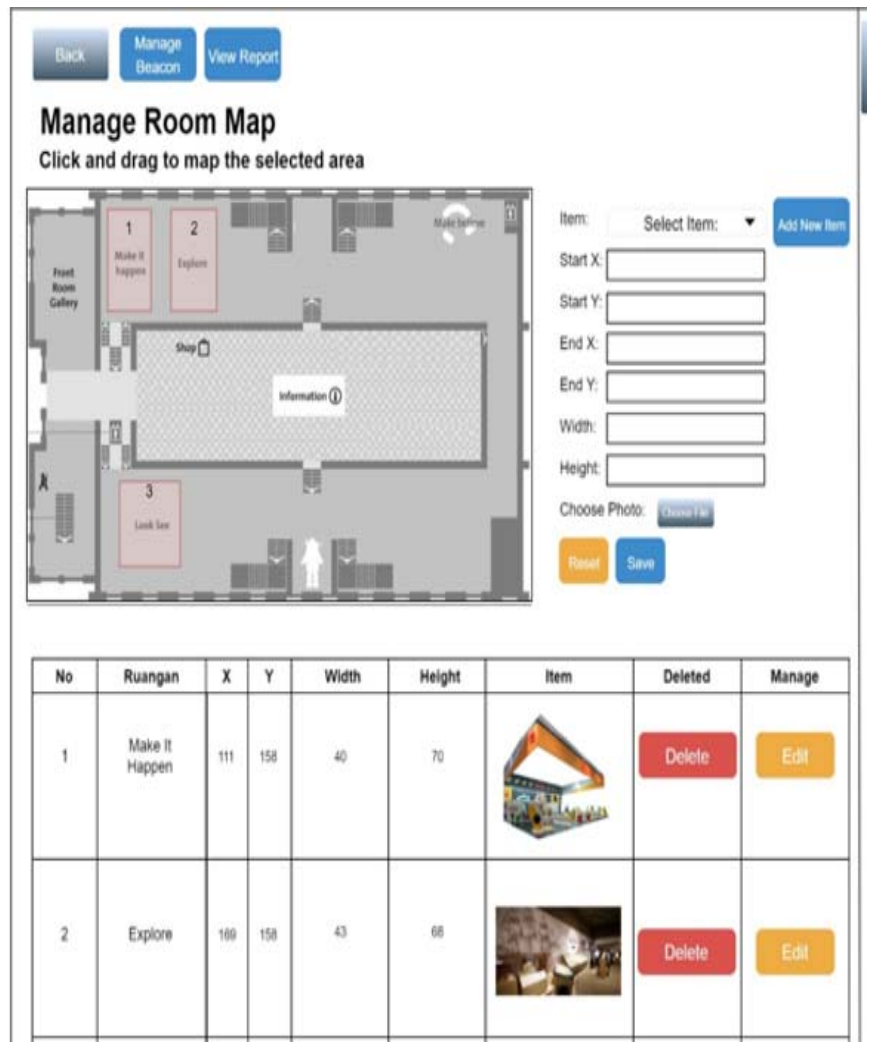

Fig. 5. Manage Museum Room Location and Information

After knowing the coordinates of the location of visitors, the system will broadcast information about the artifacts around the visitor's location (Figure 6). Visitors can view images, text information, etc.

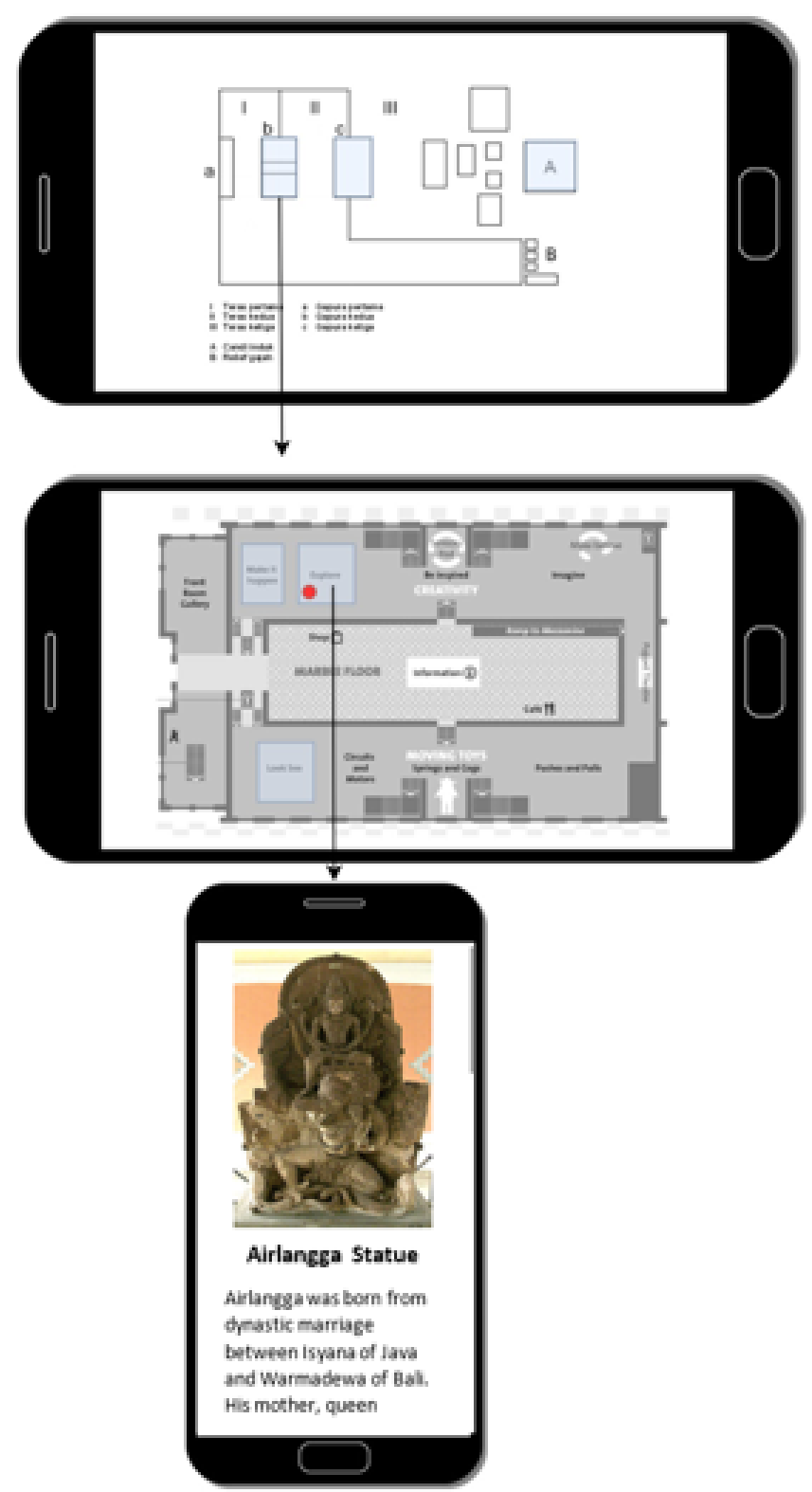

Fig. 6. Information about Artefact near Museum Visitor Location

This pilot has been tested to 85 people (from age 11-62) museum visitors. The results that obtained is that the level of user satisfaction from this application is $87 \%$. So it can be concluded that the application that made already meet user requirements.

\section{CONCLUSION}

In this research we trying to implement a museum information broadcasting application using smartphone application, Indoor Positioning System, and Bluetooth Low Energy beacon. Museum visitors can use their smartphone to receive BLE beacon signal. The application on smartphone will send di BLE beacon ID that they receive to the server then the server will gives BLE beacon location (on map). The application on smartphone will calculate BLE beacon signal strength (RSSI) and the BLE beacon location to locate the 
visitor location on the map. The server then will broadcast information about the artifact near the visitor. This information will attract the visitor to see the artifact on the museum. So, this application will give a fun and interesting visit to the museum and also indirectly a learning tools for the visitors.

In the future, this research could be improve by mapping user movement in the museum using visitors location By this information we could gather the knowledge which artefact location that visitors spend most of the time.

\section{ACKNOWLEDGMENT}

This research was supported by Indonesia Directorate Research and Technology of Higher Education under grant 002/SP2H/P/K7/KM/2018. We would also like to show our gratitude to the Mobile Computing Research Study Group for assistance to improve this research.

\section{REFERENCES}

[1] Tempo, "Tourism Donate Foreign Exchange US\$ 10 Milliard [Pariwisata Sumbang Devisa US\$ 10 Milliard]," [online] available at Tempo.com (2014) accessed 17 March 2018.

[2] Jawa Pos National Network, "Chase 20 Million Foreign Tourist and 260 Trillion IDR Foreign Exchange [Kejar 20 Juta Wisman dan Rp.260 Triliun Devisa]," [online] available at jawapos.com (2014) accessed 27 August 2018

[3] G. Gumelar, CNN Indonesia, "Indonesia Tourism Minister Claims Become the Main Contributor of Foreign Exchange" [Kemenpar Klaim Pariwisata Jadi Kontributor Utama Devisa], 2017

[4] Indonesia Tourism Ministry. "Foreign Tourist Statistics Data 2017 [Data Statistik Turis Luar Negeri 2017],” 2017

[5] UNESCO \& Indonesia Tourism Ministry, "Practical Guide for Museum Revitalization in Indonesia," UNESCO, 2011

[6] J. Borràs, A. Moreno, A. Valls, "Intelligent Tourism Recommender Systems: A Survey," Expert System with Application, pp.7370-7389, 2014, DOI: 10.1016/j.eswa.2014.06.007

[7] R.D. Egger, "The impact of near field communication on tourism", Journal of Hospitality and Tourism Technology 4(2), DOI: 10.1108/JHTT-04-2012-0014, 2018

[8] J. Pesonen \& E. Horster, "Near field communication technology in Tourism," Tourism Management Perspectives, Vol. 4, pp. 1118, DOI: 10.1016/j.tmp.2012.04.001, 2012

[9] CH. Chou, "Location Based Services for Tourism-Literature Review," Journal of Multidisciplinary Management Studies, vol 2, no 2, 2012

[10] M. Sholeh, C. Iswayudi, E.T. Prabowo, "Museum in Yogyakarta Based Location Based System [Museum di Yogyakarta Berbasis Location Based System]," Proc. National Seminar Science \& Technology Application, 2014
[11] A. Handojo, J. Andjarwirawan, S. Sunaryo, R. Lim, "Heroic battle of Surabaya application based on android," Journal of Engineering and Applied Sciences, vol. 9, no. 12, 2014

[12] M. Lailasari, D. Wulandari, A. Kurniawati, "Tourism Information Application in Ciamis District Based Mobile Phone [Aplikasi Informasi Pariwisata di Kabupaten Ciamis Berbasis Mobile Phone]," Proc. Information System National Conference, 2013

[13] H. Sulistyanto, Nurgiyatna, "Application Development Solo Raya Tourist Information System On Mobile Devices [Pengembangan Aplikasi Sistem Informasi Wisata Solo Raya pada Perangkat Mobile]," Proc. National Symposium RAPI XIII (2014)

[14] A. Handojo, R. Lim, J. Andjarwirawan, S. Sunaryo, "Games and multimedia implementation on heroic battle of Surabaya: An android based Mobile Device Application," Lecture Notes in Electrical Engineering, 365, 2016

[15] L. Botturi L, A. Inversini, A. Di Maria, "City Treasure: Mobile Games For Learning Cultural Heritage," Proc. Museum and the Web, Archives and Museums Information, 2009

[16] L. Tallon, K. Walker, "Introduction: Mobile, Digital and Personal," In: Tallon L (editors.) Digital Technologies and the Museum Experience: Handheld Guides and Other Media. Altamira Press (2008)

[17] N. Chivarov, V. Ivanova, D. Radev and I. Buzov, "Interactive Presentation of the Exhibits in the Museums Using Mobile Digital Technologies," Workshop on International Stability, Technology, and Culture The International Federation of Automatic Control, 2013

[18] H. Susanto, "Android Based Museum At Ranggawarsita Museum Semarang With Prototype Competence [Museum Berbasis Android Pada Museum Ranggawarsita Semarang Dengan Kompetensi Prototype]," Repository Dian Nuswantoro University, Semarang, 2014

[19] Y.P.W. Sari, "Information Application Museum of the Republic of Indonesia In D.K.I Jakarta Based Android [Aplikasi Informasi Museum Perjuangan Republik Indonesia Di D.K.I Jakarta Berbasis Android]," Repository Universitas Gunadarma, 2014

[20] D. Manzano, G. Villarrubia, D. Hernández, J.F. de Paz, "Indoor children location system using BLE technology", Advances in Intelligent Systems and Computing 619, pp. 148-154, 2017

[21] A. Meliones, D. Sampson,"Indoor blind navigator: A use case for self-guided tours in museums", ACM International Conference Proceeding Series Part F128530, pp. 17-20, 2017

[22] H. Yucel, R. Edizkan, T. Ozkir, and A. Yazici, "Development of indoor positioning system with ultrasonic and infrared signals," in Proc. Int. Symp. Innov. Intell. Syst. Appl., pp. 1-4, 2012

[23] C.H. Huang, L.H. Lee, C. C. Ho, L.L. Wu, Z.H. Lai., "RealTime RFID Indoor Positioning System Based on Kalman-Filter Drift Removal and Heron-Bilateration Location Estimation”, IEEE Transactions On Instrumentation And Measurement, vol. 64, no. 3, 2015. 